\title{
Narrative review of the management of oral mucositis during chemoradiation for head and neck cancer
}

\author{
Lauren F. Judge ${ }^{1}$, Mark K. Farrugia ${ }^{2}$, Anurag K. Singh ${ }^{2}$ \\ ${ }^{1}$ Jacobs School of Medicine and Biomedical Sciences, University at Buffalo, Buffalo, NY, USA; ${ }^{2}$ Department of Radiation Medicine, Roswell Park \\ Comprehensive Cancer Center, Buffalo, NY, USA \\ Contributions: (I) Conception and design: MK Farrugia, AK Singh; (II) Administrative support: MK Farrugia, AK Singh; (III) Provision of study \\ materials or patients: LF Judge; (IV) Collection and assembly of data: LF Judge; (V) Data analysis and interpretation: LF Judge; (VI) Manuscript \\ writing: All authors; (VII) Final approval of manuscript: All authors. \\ Correspondence to: Anurag K. Singh, MD. Department of Radiation Medicine, Roswell Park Comprehensive Cancer Center, 665 Elm St., Buffalo, NY, \\ USA. Email: anurag.singh@roswellpark.org.
}

\begin{abstract}
Oral mucositis $(\mathrm{OM})$ can be a significant problem for patients undergoing radiation or chemoradiation for head and neck cancer. In modern clinical trials, grade 3-4 OM can be seen in over $40 \%$ of patients and can cause a significant impact on their quality of life (QOL). Despite this fact, strategies for the prevention and treatment of OM vary widely, with options including both lifestyle modifications and pharmaceuticals. Here we evaluate and summarize the current clinical interventions for the management of radiation-induced OM. The majority of the current evidence focuses on reducing OM related pain. These agents are detailed over multiple clinical trials including treatment modalities such as: GC4419, doxepin mouthwash, diphenhydramine-lidocaine-antacid (DLA) mouthwash, gabapentin, and methadone. While several strategies have been employed to prevent radiation-induced OM, there is currently no strong evidence for the routine use of these agents in the clinic. After summarization of these treatments, we offer practical guidance for the treatment of $\mathrm{OM}$ in the clinic. We recommend a multiagent approach of pharmacological and non-pharmacological treatments including oral rinses, home humidification, escalating doses of gabapentin, doxepin or DLA mouthwash, over the counter analgesics, and lastly methadone. These interventions are tailored to address the expected increase of severity of symptoms during the course of head and neck radiotherapy.
\end{abstract}

Keywords: Radiation therapy; Head and Neck Cancer; oral mucositis (OM)

Submitted May 14, 2020. Accepted for publication Dec 31, 2020.

doi: 10.21037/atm-20-3931

View this article at: http://dx.doi.org/10.21037/atm-20-3931

\section{Introduction}

The majority of patients receiving chemoradiotherapy develop oral mucositis $(\mathrm{OM})$, with reports demonstrating grade 3 or higher $\mathrm{OM}$ in over $40 \%$ of patients despite modern radiotherapy techniques (1-3). OM has several distinct phases of evolution that can result in severe pain (4). Subsequently, OM may cause dysphagia, an increase in aspiration risk, weight loss leading to feeding tube placement, and a decrease in quality of life (QOL), culminating in the potential for an increase in treatment breaks, hospitalizations, and medical care costs (5-13).

As reviewed in Mucositis Study Group of the Multinational Association of Supportive Care in Cancer/ International Society for Oral Oncology (MASCC/ISOO), multi-agent combination oral care protocols have been shown to have efficacy for the prevention of OM during head and neck radiation therapy (14). However, these interventions largely focused on patients treated with radiation alone $(15,16)$. Overall, several interventions for the prevention and treatment of $\mathrm{OM}$, including professional oral care, multi-agent combination oral care protocols, and 


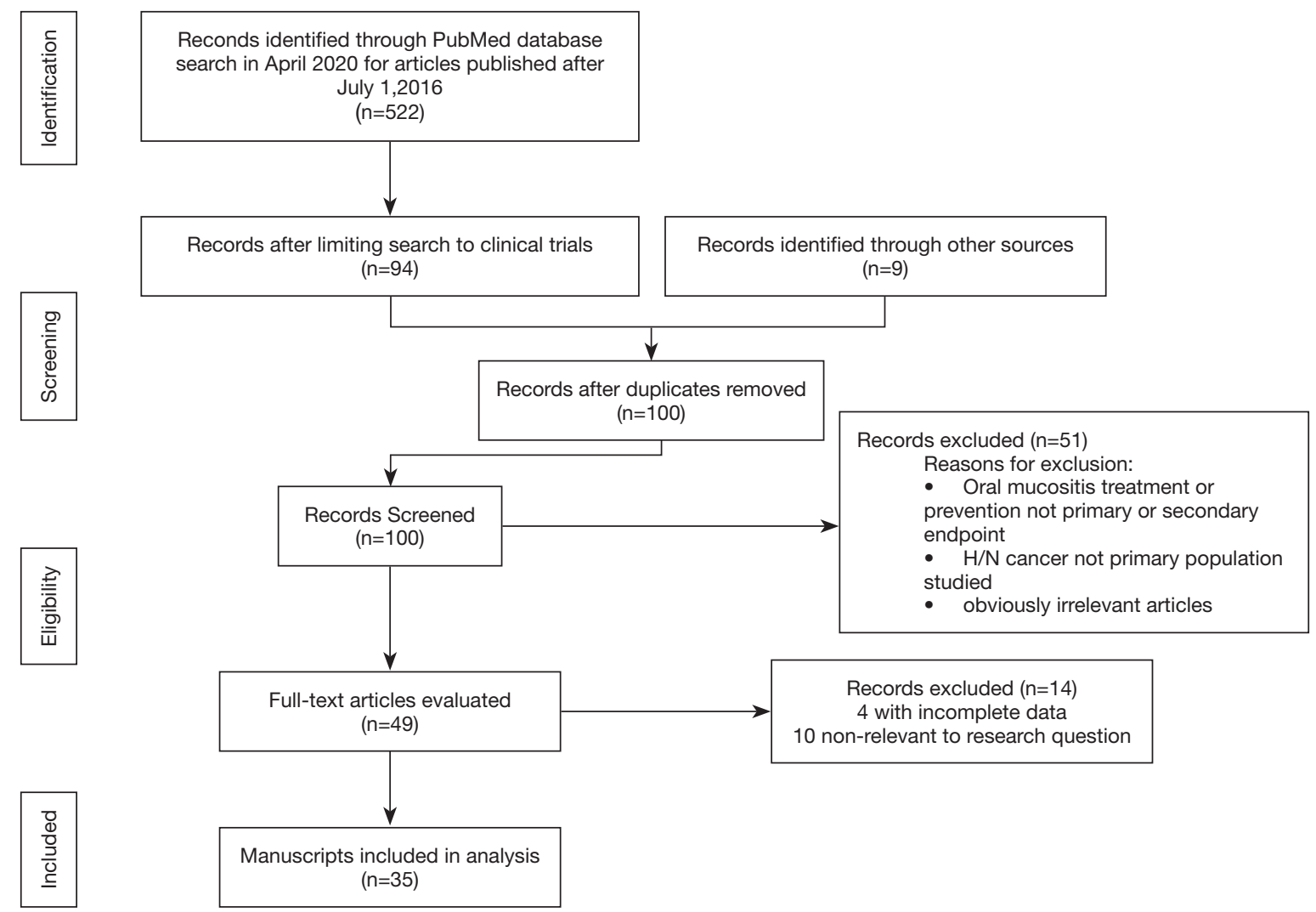

Figure 1 Preferred Reporting Items for Systematic Reviews and Meta-Analyses (PRISMA) flow diagram.

various rinses have been described (17).

Despite these overarching reviews, practical guidance on either the particular agent(s) to deploy or when to deploy them during the course of mucositis remains elusive $(14,17)$. Furthermore, several additional treatments for OM during chemoradiation for head and neck cancer, including GC4419 (18), doxepin mouthwash (19), diphenhydraminelidocaine-antacid (DLA) mouthwash (19), gabapentin (20), and methadone (20), have been published since the MASCC/ ISOO review.

We performed this review to evaluate treatment with these newer agents and offer practical guidance on how and when to deploy a therapy. We present the following article in accordance with the Narrative Review reporting checklist (available at http://dx.doi.org/10.21037/atm-20-3931).

\section{Methods}

In April 2020, the PubMed database was searched for articles detailing the clinical management of $\mathrm{OM}$ in head and neck cancer published after July 12016 , as prior to that Hong et al. detailed interventions for OM. The goal of this search was to identify studies in which OM prevention and/or treatment was a primary or secondary endpoint in head and neck cancer. Author LJ was responsible for the initial search, exclusion, and final assembly of included articles. Keywords utilized for search were "mucositis", "head and neck neoplasms", with the search query defined as (((“"mucositis”[MeSH Terms]) OR “mucositis”[Title/ Abstract] $))$ AND ((("head and neck neoplasms"[MeSH Terms])) OR ("head and neck"[Title/Abstract]))) AND (“2016/07/01"[Date - Publication]: "3000"[Date Publication]), which returned 522 results.

\section{Results}

The above search criterion identified 522 studies, of which 94 were human studies (Figure 1). In addition, we identified 9 clinical trials from the personal reference library of AS. The results from these databases were combined and 3 duplicates were removed for a total of 100 clinical trials. Of these studies, 51 were excluded because either (I) OM 


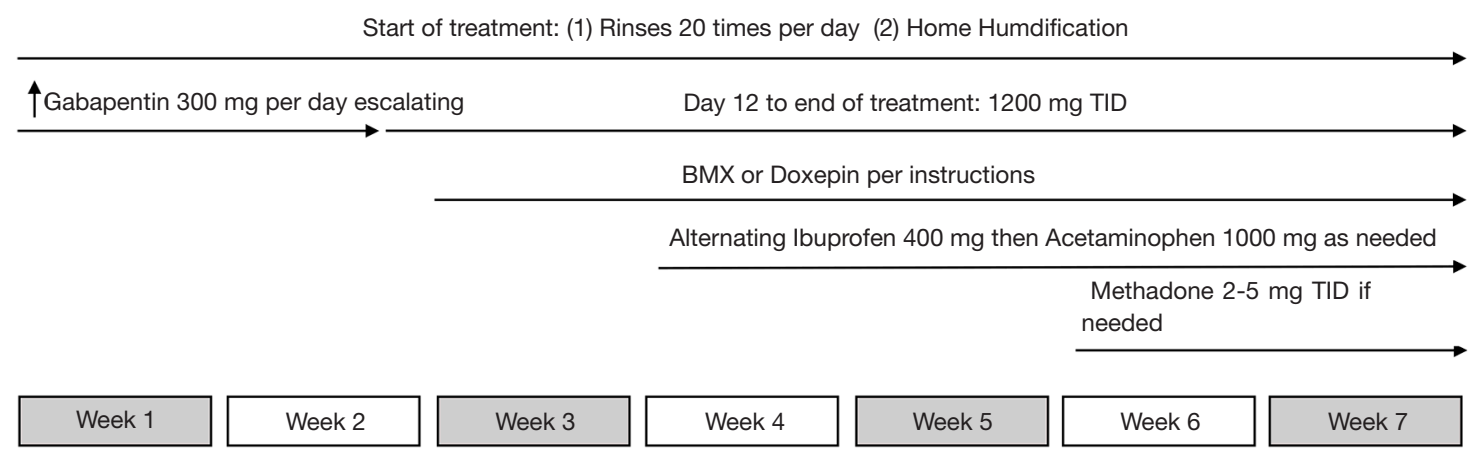

Figure 2 Oral mucositis intervention timeline.

treatment or prevention was not a primary or secondary endpoint, (II) Head and neck cancer was not the primary population studied, or (III) Study was otherwise not relevant to OM. Upon further examination of the full text, 14 additional trials were excluded as ultimately the study was not relevant or there was incomplete data for this review. Ultimately, a total of 35 clinical trials were included in this review.

\section{Discussion}

This review summarizes the literature since 2016 for the management of $\mathrm{OM}$ in head and neck cancer patients. Moreover, we synthesize the literature into a practical guideline of how to integrate various clinically available therapies to mitigate $\mathrm{OM}$ during chemoradiation therapy for head and neck cancer.

A multi-agent approach, in agreement with previous recommendations (14), remains necessary. The rational combination of agents should be designed to optimize both short- and long-term pain relief (Figure 2). This is illustrated and explained as a 1-page hand out in Appendix 1.

We recommend initiating home humidification, oral rinses and gabapentin at the beginning of treatment. Macann et al. treated patients used humidifiers overnight with additional use throughout the day from the first day of RT for 12 weeks (21). Humidification was found to result in a decrease in the development of functional mucositis. Additionally, treated patients had lower feeding tube use, and a lower risk of being admitted to the hospital. However, patient compliance was an issue. Many patients already have treatment for sleep apnea and their positive pressure devices may achieve some of this effect. Anecdotally, patients also report some benefit with a cool mist humidifier placed by the bed.

The importance of mucosal hydration in ameliorating toxicity is consistent with data showing that in the middle of radiation therapy, patients with worse mucositis pain also have worse dehydration (22). Intravenous fluids during this period can significantly and immediately reduce this pain (Rivers et al., manuscript submitted).

Saline oral rinses in our case are composed of tap water, sodium chloride, and sodium bicarbonate with recommended daily rinses of at least 20 times a day (Appendix 1). Oral care is commonly recommended to reduce the incidence of $\mathrm{OM}$, however this is not based on strong evidence (14). However, they are commonly used, helpful for oral hygiene, and appear to be otherwise harmless. Clinically, while we are quite vigilant about the use of prescription medications, we understand the weakness of the oral care data and only adamantly require its' use in those patients with a large increase in mucus.

Gabapentin, originally developed as an anti-convulsant agent, has been shown to have efficacy in the treatment of neuropathic pain (23). Sharp et al. found that gabapentin reduced mucosal neuropathy in two patients who had a received a trial of gefitinib and paclitaxel (24). Gabapentin should be slowly escalated from 300 daily to $1,200 \mathrm{mg}$ three times per day. The use of high dose gabapentin is based on the experience of our on-going current study and Hermann et al. who found that high dose gabapentin resulted in a significantly greater percentage of patients never requiring opioids (42\% vs. 7\%, $\mathrm{P}=0.002$ ) (20) (ClinicalTrials.gov identifier NCT 03547492). Several prospective trials demonstrated that gabapentin can reduce the need for enteric feeding tubes and narcotics, as well as improve QoL despite no significant impact on OM incidence or severity (20,25-27). While gabapentin does require an initial dose escalation, overall it has a favorable 
side-effect profile. As such, we recommend the use of prophylactic gabapentin in this setting. Gabapentin is renally excreted and the total dose should be limited in those with a baseline creatinine clearance below 60 milliliters/minute. In practice we have not had any toxicities in those patients taking 3,600 mg daily who were later found to have asymptomatic cisplatin induced acute renal failure; this was treated with intravenous hydration and monitoring without change in the gabapentin dose.

At the development of symptomatic OM, we recommend initiating either doxepin or DLA mouthwash. DLA can be used as a mouth and/or throat wash, or used to treat select sore areas via a sponge stick. Sio et al. evaluated the use of doxepin or DLA mouthwashes for the reduction of OM related pain (19). Both interventions were successful at reducing pain at 4 hours without significantly impacting median overall pain scores. The study was not designed to make comparisons between each agent, therefore we recommend either doxepin or DLA mouthwashes for shortterm OM-related pain.

When pain is no longer adequately controlled via this regimen, we recommend introducing alternating doses of ibuprofen and acetaminophen. Patients are instructed to start Ibuprofen $400 \mathrm{mg}$ and 4 hours later, take Acetaminophen $1,000 \mathrm{mg}$. This can be repeated every 6-8 hours however maximum recommended daily dose of Acetaminophen is $3,000 \mathrm{mg}$. There is no current guideline regarding the use of over-the-counter analgesics such as ibuprofen or acetaminophen (14). These medications have a wellestablished role for pain-relief however the role in the treatment of $\mathrm{OM}$ is unclear. Nevertheless, given the favorable side-effect profile and potential to relief OM-related pain, it is reasonable to utilize these medications in this setting.

In the last weeks of treatment, many patients have difficulty achieving adequate pain relief and require narcotics. We recommend methadone $2 \mathrm{mg}$ three times a day to supplement the above regimen. In our experience it is rare to require more than $5 \mathrm{mg}$ of methadone three times per day and we have never escalated a patient beyond $10 \mathrm{mg}$ three times per day. Methadone may be more effective for neuropathic pain and unlike other opiates, methadone has a long half-life, therefore providing prolonged pain relief (28). Methadone, when used in conjunction with gabapentin, improves pain control and several QoL/function metrics $(20,29)$. While it is unclear whether high dose gabapentin adds additional benefit to methadone, we recommend the use of methadone for pain relief in patients not well controlled on high dose gabapentin and over-counter-analgesics. Additionally, in order to reduce opioid-constipation, we recommend a stool softener with laxatives as needed to be taken in conjunction with methadone.

Methadone is thought to work in minimizing neuropathic pain due to its action on the N-Methyl-D-Aspartate receptor (20). Methadone also has a long half-life, which provides long acting pain relief (28). Haumann et al. ran two RCTs to compare the use of methadone to fentanyl in both nociceptive and neuropathic pain domains in OM. Opioidnaïve patients reported significantly decreased average pain with the use of methadone at 3 weeks of treatment (29). In addition, all measures demonstrated noninferiority of methadone to fentanyl, with no difference in side effect profile. Likewise, in a neuropathic pain focused trial, patients reported significantly decreased average pain with the use of methadone at weeks 1 and 3 of treatment (30). Hermann et al. found that use of methadone lowered total narcotic requirements and significantly improved several QOL domains (20).

In terms of OM prevention, there are no well-validated strategies to significantly reduce the development of OM. While modern techniques for radiation therapy have increased capacity for tissue sparing, often a significant dose to the head and neck mucosa is unavoidable due to its proximity to tumor and electively covered regions (31). Another common approach of radioprotection is to mitigate the radiation-induced damage through reduction and/ or quenching of reactive-oxygen species. Initial studies of GC4419 have shown a reduction of incidence, duration, and severity of OM $(18,32)$. Results from a phase 3 study, currently underway, are eagerly anticipated. However, this compound requires daily infusions which may limit its use by some patients or physicians.

Reports examining amino acid \& amino acid derivatives for $\mathrm{OM}$ are either preliminary or have shown no benefit (33-41). Similarly, no recommendation can be made on the use of alternative therapies. Low-level laser therapy (LLLT) has promising limited data which requires additional study; however, LLLT requires technology which is not widely available $(42,43)$. Similarly, the other positive clinical trials reported in Table 1 merit further consideration and research but are not yet widely clinically applicable.

Additional interventions which are not directly related to OM can still benefit patients. The use of NSAIDs was recently shown to be associated with an improvement in overall survival in head and neck cancer patients (70). As such, we recommend that patients take a low-dose or baby aspirin 
Table 1 Trials reported for oral mucositis interventions

\begin{tabular}{|c|c|c|c|c|c|c|c|c|c|c|c|}
\hline \multirow[b]{2}{*}{ Intervention } & \multirow[b]{2}{*}{ Type } & \multirow[b]{2}{*}{ Modality } & \multirow[b]{2}{*}{ Indication } & \multicolumn{5}{|c|}{ Effectiveness } & \multirow[b]{2}{*}{ Participants } & \multirow[b]{2}{*}{ Key findings } & \multirow[b]{2}{*}{ Author, Year } \\
\hline & & & & $\begin{array}{c}\text { OM } \\
\text { incidence }\end{array}$ & $\begin{array}{l}\text { OM } \\
\text { Severity }\end{array}$ & Duration & $\begin{array}{l}\text { Pain Pain } \\
\text { severity duration }\end{array}$ & $\begin{array}{l}\text { Overall } \\
\text { Qol }\end{array}$ & & & \\
\hline \multicolumn{12}{|c|}{ Amino acids \& amino acid derivatives } \\
\hline \multirow[t]{2}{*}{ D-Methionine } & Prospective & CT \& RT & Prevention & $\mathrm{Y}$ & $\mathrm{N}$ & & & & 29 treated, 29 control & Lower rate of overall mucositis & Hamstra 2018 (34) \\
\hline & & & & & & & & & & No difference in amount of grade $3 / 4 \mathrm{OM}$ & \\
\hline Dusquetide & Prospective & CT \& RT & Prevention & & & $\mathrm{Y}$ & & & $\begin{array}{l}41 \text { treated with } 1.5 \mathrm{mg} / \mathrm{kg}, 3 \text { treated with } 3.0 \mathrm{mg} / \mathrm{kg} \text {, } \\
24 \text { treated with } 6.0 \mathrm{mg} / \mathrm{kg}, 43 \text { control }\end{array}$ & Reduced duration of OM & Kudrimoti 2016 (35) \\
\hline Glutamine & Prospective & RT & Prevention & & $\mathrm{N}$ & & & & 31 treated, 33 placebo & No difference in severity of OM & Huang 2019 (44) \\
\hline \multirow[t]{2}{*}{$\mathrm{HMB} / \mathrm{Arg} / \mathrm{Gln}$} & Prospective & CT \& RT & Prevention & $\mathrm{N}$ & & $\mathrm{Y}$ & & & $\begin{array}{l}35 \text { treated, compared against previous opioid based pain } \\
\text { control and oral car programs }\end{array}$ & No difference in incidence of grade 3 or greater OM & Yokota 2018 (39) \\
\hline & & & & & & & & & & Reduced duration of OM & \\
\hline Rebamipide & Prospective & CT \& RT & Treatment & $\mathrm{Y}^{*}$ & & & & & 31 treated with $2 \%, 32$ treated with $4 \%, 31$ control & Decreased incidence of grade $3 \mathrm{OM}^{*}$ & Yokota 2017 (40) \\
\hline \multirow[t]{2}{*}{ Rebamipide } & Prospective & CT \& RT & Prevention & & $\mathrm{Y}$ & $\mathrm{Y}$ (onset) & & & 30 treated, 30 control & Delay of 3.5 days in the onset of $\mathrm{OM}$ & Chaitanya 2017 (33) \\
\hline & & & & & & & & & & Decreased OM pain score & \\
\hline \multirow[t]{2}{*}{ Benzydamine $\mathrm{HCl}$} & Prospective & CT \& RT & Prevention & & $\mathrm{Y}$ & & $\mathrm{N}$ & & 30 treated, 30 control & Lower median OM Assessment Scale score & Chitapanarux $2018(45)$ \\
\hline & Prospective & CT\&RT & Prevention & $\mathrm{Y}^{* *}$ & & & & & $\begin{array}{l}62 \text { treated (29 RT only, } 33 \text { CRT), } 58 \text { control ( } 28 \text { RT only, } 30 \\
\text { CRT) }\end{array}$ & $\begin{array}{l}\text { Decreased incidence of grade } 3 \text { OM in RT only group, no difference in incidence in CRT } \\
\text { group** }\end{array}$ & Rastogi 2017 (46) \\
\hline \multirow[t]{2}{*}{ Caphosol } & Prospective & CT \& RT & Prevention & $\mathrm{N}$ & & $\mathrm{N}$ & & & 108 treated, & No difference in the incidence of severe $\mathrm{OM}$ & Wong 2017 (47) \\
\hline & & & & & & & & & 107 control & No difference in duration of severe OM & \\
\hline \multirow{2}{*}{ Clonidine Mucoadhesive Tablets } & & & & & & & & & & Later onset of $\mathrm{OM}^{*}$ & \\
\hline & & & & & & & & & & No difference in mouth or throat soreness & \\
\hline Doxepin Mouthwash & Prospective & CT \& RT & Treatment & & & & $\mathrm{Y}$ & & 92 treated, 92 control & Decreased OM pain score, but not clinically significant & Sio 2019 (19) \\
\hline $\begin{array}{l}\text { Diphenhydramine-Lidocaine- } \\
\text { Antacid }\end{array}$ & Prospective & CT\&RT & Treatment & & & & $\mathrm{Y}$ & & 91 treated, 92 control & Decreased OM pain score, but not clinically significant & Sio 2019 (19) \\
\hline \multirow[t]{2}{*}{ Education Programme } & Prospective & CT \& RT & Treatment & & & & $\mathrm{N}$ & $\mathrm{N}$ & 51 treated, 45 control & Better physical \& social-emotional QoL, no difference on overall QoL & Huang 2018 (49) \\
\hline & & & & & & & & & & No difference in severity of symptoms of OM & \\
\hline \multirow[t]{5}{*}{ Gabapentin } & Retrospective & RT & $\begin{array}{l}\text { Prevention } \\
\text { \& Treatment }\end{array}$ & & & & $\mathrm{Y}$ & & 30 treated, median dose $2700 \mathrm{mg}$ & $\begin{array}{l}\text { Only } 10 \% \text { of patients used narcotic pain medication during the third and fourth weeks of } \\
\text { treatment despite } 56 \% \text { and } 73 \% \text { of patients having grade } 2+\text { OM }\end{array}$ & Bar Ad 2010 (25) \\
\hline & & & & & & & & & & $\begin{array}{l}\text { Only } 35 \% \text { of patients used narcotic pain medication during the fifth and sixth weeks of } \\
\text { treatment despite } 80 \% \text { have grade } 2+\mathrm{OM}\end{array}$ & \\
\hline & Retrospective & CT \& RT & $\begin{array}{l}\text { Prevention } \\
\text { \& Treatment }\end{array}$ & & & & $\mathrm{Y}$ & & 42 treated, median dose $2700 \mathrm{mg}$ & $\begin{array}{l}\text { Only } 33 \% \text { of patients used narcotic pain medication during the third weeks of treatment } \\
\text { despite } 71 \% \text { of patients having grade } 2+\mathrm{OM}\end{array}$ & Bar Ad 2010 (26) \\
\hline & & & & & & & & & & $\begin{array}{l}\text { Only } 55 \% \text { of patients used narcotic pain medication during the third weeks of treatment } \\
\text { despite } 86 \% \text { of patients having grade } 2+\text { OM }\end{array}$ & \\
\hline & & & & & & & & & & $\begin{array}{l}\text { Only } 71 \% \text { of patients used narcotic pain medication during the fifth and sixth weeks of } \\
\text { treatment despite } 95 \% \text { and } 100 \% \text { having grade } 2+\text { OM }\end{array}$ & \\
\hline
\end{tabular}

Table 1 (continued) 
Table 1 (continued)

\begin{tabular}{|c|c|c|c|c|c|c|c|c|c|c|c|c|}
\hline \multirow[b]{2}{*}{ Intervention } & \multirow[b]{2}{*}{ Type } & \multirow[b]{2}{*}{ Modality } & \multirow[b]{2}{*}{ Indication } & \multicolumn{6}{|c|}{ Effectiveness } & \multirow[b]{2}{*}{ Participants } & \multirow[b]{2}{*}{ Key findings } & \multirow[b]{2}{*}{ Author, Year } \\
\hline & & & & $\begin{array}{c}\text { OM } \\
\text { incidence }\end{array}$ & $\begin{array}{l}\text { OM } \\
\text { Severity }\end{array}$ & y Duration & $\begin{array}{c}\text { Pain } \\
\text { severity }\end{array}$ & $\begin{array}{l}\text { Pain } \\
\text { duration }\end{array}$ & $\begin{array}{l}\text { Overall } \\
\text { QoL }\end{array}$ & & & \\
\hline & Retrospective & RT & $\begin{array}{l}\text { Prevention } \\
\text { \& Treatment }\end{array}$ & & & & $\mathrm{Y}$ & & & $\begin{array}{l}31 \text { treated, } \\
33 \text { controls }\end{array}$ & Less weight loss & Dong 2016 (50) \\
\hline & Prospective & CT \& RT & $\begin{array}{l}\text { Prevention } \\
\text { \& Treatment }\end{array}$ & & & & $\mathrm{Y}$ & & & 2 treated & Reduction in dysesthesia despite OM & Sharp $2008(24)$ \\
\hline & Prospective & CT \& RT & $\begin{array}{l}\text { Prevention } \\
\text { \& Treatment }\end{array}$ & & & & $\mathrm{Y}$ & $\mathrm{Y}$ & $\mathrm{Y}$ & 23 treated & Later initiation of PEG tube use & Starmer 2014 (27) \\
\hline & & & & & & & & & & & Earlier cessation of PEG tube use & \\
\hline & & & & & & & & & & & Lower PAS scores & \\
\hline & & & & & & & & & & & Higher FIOS scores & \\
\hline & Prospective & CT \& RT & $\begin{array}{l}\text { Prevention } \\
\text { \& Treatment }\end{array}$ & & & & $\mathrm{Y}$ & & & $\begin{array}{l}31 \text { treated with } 2700 \mathrm{mg} \text { gabapentin + standard of care, } 29 \\
\text { treated with } 900 \mathrm{mg} \text { dose + methadone }\end{array}$ & Later initiation of narcotic medication & Hermann $2020(20)$ \\
\hline & & & & & & & & & & & Higher number of patients never needing opioids & \\
\hline & Prospective & CT \& RT & Treatment & & & & $\mathrm{N}$ & $\mathrm{N}$ & & 11 treated, 11 control & Less weight gain & Kataoka 2016 (51) \\
\hline & & & & & & & & & & & No difference in OM pain score & \\
\hline & & & & & & & & & & & No difference in initiation of opioids & \\
\hline & & & & & & & & & & & No difference in median total dose of opioids & \\
\hline GC4419 & & & & & & & & & & & 40mg dose reduced OM duration, incidence and severity* & \\
\hline Indomethacin Spray & Prospective & $\mathrm{CT} \& \mathrm{RT}$ & Treatment & & & & $\mathrm{Y}$ & & & 35 treated & Decrease in pain score after applying treatment & Momo 2017 (52) \\
\hline \multirow[t]{2}{*}{ Lactobacillus Brevis CD2 } & Prospective & $\mathrm{CT} \& \mathrm{RT}$ & Prevention & $\mathrm{N}$ & & & & & $\mathrm{N}$ & 32 treated, 36 control & No difference in incidence of severe OM & De Sanctis 2019 (53) \\
\hline & & & & & & & & & & & No difference in QoL or weight loss & \\
\hline \multirow[t]{6}{*}{ LLLT } & Prospective & CT \& RT & Prevention & $\mathrm{N}$ & & $Y^{*}$ (onset) & $\mathrm{N}$ & & $\mathrm{N}$ & 42 treated, 41 control & No difference in incidence of grade $3 \mathrm{OM}$ & Legouté 2019 (54) \\
\hline & & & & & & & & & & & Later onset of $\mathrm{OM}^{*}$ & \\
\hline & & & & & & & & & & & No difference in overall QoL measures & \\
\hline & & & & & & & & & & & No difference in OM pain scores & \\
\hline & Prospective & $\mathrm{CT} \& \mathrm{RT}$ & Prevention & $\mathrm{Y}$ & & $\mathrm{Y}$ & & & & 11 treated, 15 control & More grade $0 \mathrm{OM}$ during week 1 & Marín-Conde 2019 (42) \\
\hline & & & & & & & & & & & Decreased duration of clinical OM & \\
\hline \multirow[t]{4}{*}{ Methadone } & Prospective & $\mathrm{CT} \& \mathrm{RT}$ & Treatment & & & & $\mathrm{Y}$ & & & 26 treated, 26 control & $\begin{array}{l}\text { Decreased OM pain score at weeks } 1,3 \text { \& } 5 \text {, significant at weeks } 1 \text { \& } 3 \text { compared to } \\
\text { Fentanyl }\end{array}$ & Haumann $2016(30)$ \\
\hline & Prospective & RT & Treatment & & & & $\mathrm{Y}$ & & & 42 treated with methadone, 40 treated with fentanyl & Noninferiority of Methadone to Fentanyl for pain reduction at weeks 1 and 3 & Haumann $2018(29)$ \\
\hline & Prospective & $\mathrm{CT} \& \mathrm{RT}$ & Treatment & & & & $\mathrm{N}$ & & $\mathrm{Y}$ & $\begin{array}{l}29 \text { treated with } 900 \mathrm{mg} \text { dose + methadone, } 31 \text { treated with } \\
2700 \mathrm{mg} \text { gabapentin + standard of care }\end{array}$ & Reduced insomnia & Hermann $2020(20)$ \\
\hline & & & & & & & & & & & Reduced fatigue $^{*}$ & \\
\hline
\end{tabular}


Table 1 (continued)

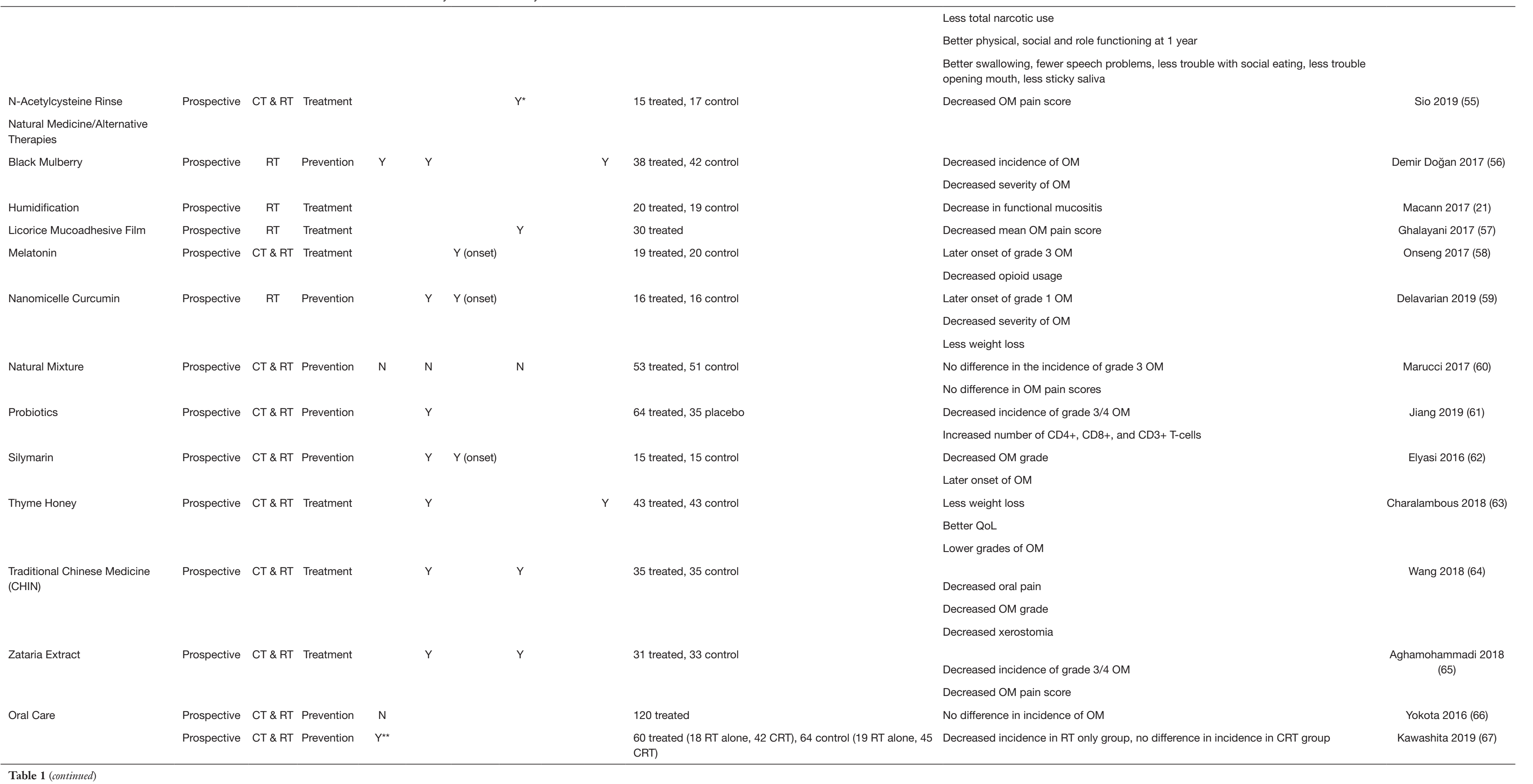


Table 1 (continued)

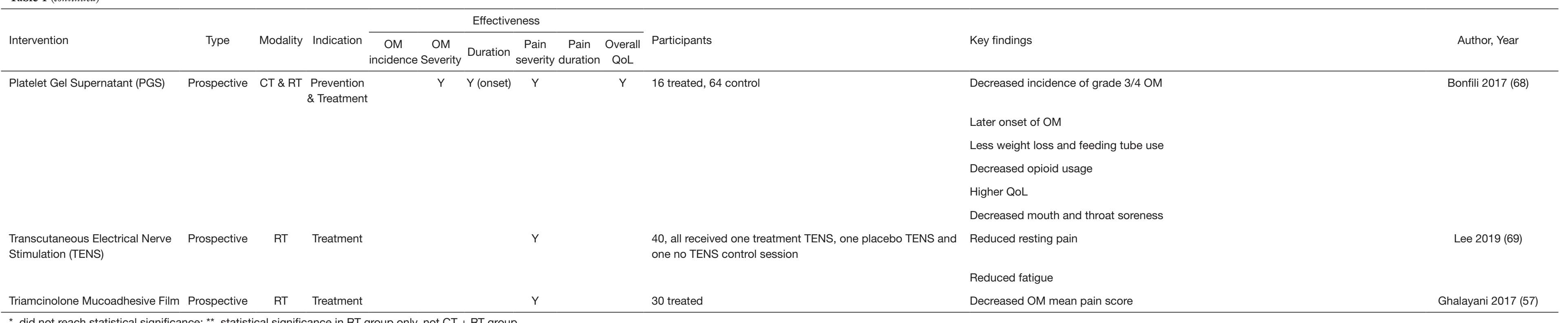

*, did not reach statistical significance; **, statistical significance in RT group only, not CT + RT group. 
prior to and indefinitely after therapy. Radiation dermatitis is a distinct entity from $\mathrm{OM}$, however it can contribute to the overall pain profile of a patient. Barrier ointments are frequently used to treat radiation dermatitis (71).

There are limitations to this review. We recognize that some of the interventions, namely humidification, saline rinses, and over the counter analgesics, are not based on rigorous studies. Nevertheless, we feel that these recommendations are reasonable based on clinical experience and the relative benign nature of the treatment.

In conclusion, this review highlights a variety of different clinical interventions aimed at alleviating $\mathrm{OM}$ in head and neck cancer, favoring a multi-agent approach to this difficult problem. Non-pharmacologic interventions such as humification and saline rinses can be started immediately which may provide symptom relief without potential harm to the patient. Mitigation of OM-related pain can also begin immediately via a tapered increase of Gabapentin. As an adjunct, medicated mouthwashes such as DLA or doxepin can be used for short-term pain relief to aid in eating and drinking. Other strategies to improve pain control during the course of treatment include over the counter analgesics, followed by methadone if OM-related pain continues to be poorly controlled. Future studies include investigating whether other agents for neuropathic pain, such as the selective norepinephrine uptake inhibitors, can be effective in treating OM-related pain. Currently, we are exploring whether the addition of venlafaxine to the gabapentin regimen improves pain control and reduces opioid use in the treatment of head and neck cancer.

\section{Acknowledgments}

We thank Kelsey Bezon PA for her active management of our patients and contributions to the development of our current institutional guidelines.

Funding: None.

\section{Footnote}

Provenance and Peer Review: This article was commissioned by the Guest Editor (Dr. Mukund Seshadri) for the series "Head and Neck Cancers - Disease Biology, Diagnostics, Prevention and Management" published in Annals of Translational Medicine. The article has undergone external peer review.

Reporting Checklist: The authors have completed the
Narrative Review reporting checklist. Available at http:// dx.doi.org/10.21037/atm-20-3931

Conflicts of Interest: The authors have completed the ICMJE uniform disclosure form (available at http://dx.doi. org/10.21037/atm-20-3931). The series "Head and Neck Cancers - Disease Biology, Diagnostics, Prevention and Management" was commissioned by the editorial office without any funding or sponsorship. The authors have no other conflicts of interest to declare.

Ethical Statement: The authors are accountable for all aspects of the work in ensuring that questions related to the accuracy or integrity of any part of the work is appropriately investigated and resolved.

Open Access Statement: This is an Open Access article distributed in accordance with the Creative Commons Attribution-NonCommercial-NoDerivs 4.0 International License (CC BY-NC-ND 4.0), which permits the noncommercial replication and distribution of the article with the strict proviso that no changes or edits are made and the original work is properly cited (including links to both the formal publication through the relevant DOI and the license). See: https://creativecommons.org/licenses/by-nc-nd/4.0/.

\section{References}

1. Vera-Llonch M, Oster G, Hagiwara M, et al. Oral mucositis in patients undergoing radiation treatment for head and neck carcinoma. Cancer 2006;106:329-36.

2. Elting LS, Cooksley CD, Chambers MS, et al. Risk, outcomes, and costs of radiation-induced oral mucositis among patients with head-and-neck malignancies. Int J Radiat Oncol Biol Phys 2007;68:1110-20.

3. Gillison ML, Trotti AM, Harris J, et al. Radiotherapy plus cetuximab or cisplatin in human papillomavirus-positive oropharyngeal cancer (NRG Oncology RTOG 1016): a randomised, multicentre, non-inferiority trial. Lancet 2019;393:40-50.

4. Sonis ST. The pathobiology of mucositis. Nat Rev Cancer 2004:4:277-84.

5. McCloskey SA, Jaggernauth W, Rigual NR, et al. Radiation treatment interruptions greater than one week and low hemoglobin levels $(12 \mathrm{~g} / \mathrm{dL})$ are predictors of local regional failure after definitive concurrent chemotherapy and intensity-modulated radiation therapy for squamous cell carcinoma of the head and neck. Am J Clin Oncol 
2009;32:587-91.

6. Platek ME, McCloskey SA, Cruz M, et al. Quantification of the effect of treatment duration on local-regional failure after definitive concurrent chemotherapy and intensitymodulated radiation therapy for squamous cell carcinoma of the head and neck. Head Neck 2013;35:684-8.

7. Platek ME, Myrick E, McCloskey SA, et al. Pretreatment weight status and weight loss among head and neck cancer patients receiving definitive concurrent chemoradiation therapy: implications for nutrition integrated treatment pathways. Support Care Cancer 2013;21:2825-33.

8. Platek ME, Reid ME, Wilding GE, et al. Pretreatment nutritional status and locoregional failure of patients with head and neck cancer undergoing definitive concurrent chemoradiation therapy. Head Neck 2011;33:1561-8.

9. Rose-Ped AM, Bellm LA, Epstein JB, et al. Complications of radiation therapy for head and neck cancers. The patient's perspective. Cancer Nurs 2002;25:461-7; quiz 8-9.

10. Strom T, Trotti AM, Kish J, et al. Risk factors for percutaneous endoscopic gastrostomy tube placement during chemoradiotherapy for oropharyngeal cancer. JAMA Otolaryngol Head Neck Surg 2013;139:1242-6.

11. Trotti A. Toxicity in head and neck cancer: a review of trends and issues. Int J Radiat Oncol Biol Phys 2000;47:1-12.

12. Kramer S, Newcomb M, Hessler J, et al. Prophylactic versus reactive PEG tube placement in head and neck cancer. Otolaryngol Head Neck Surg 2014;150:407-12.

13. Nonzee NJ, Dandade NA, Patel U, et al. Evaluating the supportive care costs of severe radiochemotherapyinduced mucositis and pharyngitis: results from a Northwestern University Costs of Cancer Program pilot study with head and neck and nonsmall cell lung cancer patients who received care at a county hospital, a Veterans Administration hospital, or a comprehensive cancer care center. Cancer 2008;113:1446-52. Erratum in: Cancer 2009; $115: 2805$.

14. Hong CHL, Gueiros LA, Fulton JS, et al. Systematic review of basic oral care for the management of oral mucositis in cancer patients and clinical practice guidelines. Support Care Cancer 2019;27:3949-67.

15. Kartin PT, Tasci S, Soyuer S, et al. Effect of an oral mucositis protocol on quality of life of patients with head and neck cancer treated with radiation therapy. Clin J Oncol Nurs 2014;18:E118-25.

16. Shieh SH, Wang ST, Tsai ST, et al. Mouth care for nasopharyngeal cancer patients undergoing radiotherapy. Oral Oncol. 1997;33:36-41.

17. Maria OM, Eliopoulos N, Muanza T. Radiation-Induced
Oral Mucositis. Front Oncol 2017;7:89.

18. Anderson CM, Sonis ST, Lee CM, et al. Phase 1b/2a Trial of the Superoxide Dismutase Mimetic GC4419 to Reduce Chemoradiotherapy-Induced Oral Mucositis in Patients With Oral Cavity or Oropharyngeal Carcinoma. Int J Radiat Oncol Biol Phys 2018;100:427-35.

19. Sio TT, Le-Rademacher JG, Leenstra JL, et al. Effect of Doxepin Mouthwash or Diphenhydramine-LidocaineAntacid Mouthwash vs Placebo on Radiotherapy-Related Oral Mucositis Pain: The Alliance A221304 Randomized Clinical Trial. JAMA 2019;321:1481-90.

20. Hermann GM, Iovoli AJ, Platek AJ, et al. A singleinstitution, randomized, pilot study evaluating the efficacy of gabapentin and methadone for patients undergoing chemoradiation for head and neck squamous cell cancer. Cancer 2020;126:1480-91.

21. Macann A, Fauzi F, Simpson J, et al. Humidification mitigates acute mucosal toxicity during radiotherapy when factoring volumetric parameters. Trans Tasman Radiation Oncology Group (TROG) RadioHUM 07.03 substudy. Oral Oncol 2017;75:75-80.

22. Brzozowska A, Mlak R, Golebiowski P, et al. Status of hydration assessed by bioelectrical impedance analysis: a valuable predictive factor for radiation-induced oral mucositis in head and neck cancer patients. Clin Transl Oncol 2019;21:615-20.

23. Bar Ad V. Gabapentin for the treatment of cancer-related pain syndromes. Rev Recent Clin Trials 2010;5:174-8.

24. Sharp H, Morris JC, Van Waes C, et al. High incidence of oral dysesthesias on a trial of gefitinib, Paclitaxel, and concurrent external beam radiation for locally advanced head and neck cancers. Am J Clin Oncol 2008;31:557-60.

25. Bar Ad V, Weinstein G, Dutta PR, et al. Gabapentin for the treatment of pain related to radiation-induced mucositis in patients with head and neck tumors treated with intensity-modulated radiation therapy. Head Neck 2010;32:173-7.

26. Bar Ad V, Weinstein G, Dutta PR, et al. Gabapentin for the treatment of pain syndrome related to radiationinduced mucositis in patients with head and neck cancer treated with concurrent chemoradiotherapy. Cancer 2010;116:4206-13.

27. Starmer HM, Yang W, Raval R, et al. Effect of gabapentin on swallowing during and after chemoradiation for oropharyngeal squamous cell cancer. Dysphagia 2014;29:396-402. Erratum in: Dysphagia 2014;29:403.

28. Manfredonia JF. Prescribing methadone for pain management in end-of-life care. J Am Osteopath Assoc 
2005;105:S18-21.

29. Haumann J, van Kuijk SMJ, Geurts JW, et al. Methadone versus Fentanyl in Patients with Radiation-Induced Nociceptive Pain with Head and Neck Cancer: A Randomized Controlled Noninferiority Trial. Pain Pract 2018;18:331-40.

30. Haumann J, Geurts JW, van Kuijk SM, et al. Methadone is superior to fentanyl in treating neuropathic pain in patients with head-and-neck cancer. Eur J Cancer 2016;65:121-9.

31. Eisbruch A, Harris J, Garden AS, et al. Multi-institutional trial of accelerated hypofractionated intensity-modulated radiation therapy for early-stage oropharyngeal cancer (RTOG 00-22). Int J Radiat Oncol Biol Phys 2010;76:1333-8.

32. Anderson CM, Lee CM, Saunders DP, et al. Phase IIb, Randomized, Double-Blind Trial of GC4419 Versus Placebo to Reduce Severe Oral Mucositis Due to Concurrent Radiotherapy and Cisplatin For Head and Neck Cancer. J Clin Oncol 2019;37:3256-65.

33. Chaitanya B, Pai KM, Yathiraj PH, et al. Rebamipide gargle in preventive management of chemo-radiotherapy induced oral mucositis. Oral Oncol 2017;72:179-82.

34. Hamstra DA, Lee KC, Eisbruch A, et al. Double-blind placebo-controlled multicenter phase II trial to evaluate D-methionine in preventing/reducing oral mucositis induced by radiation and chemotherapy for head and neck cancer. Head Neck 2018;40:1375-88.

35. Kudrimoti M, Curtis A, Azawi S, et al. Dusquetide: A novel innate defense regulator demonstrating a significant and consistent reduction in the duration of oral mucositis in preclinical data and a randomized, placebo-controlled phase 2a clinical study. J Biotechnol 2016;239:115-25.

36. Vuyyuri SB, Hamstra DA, Khanna D, et al. Evaluation of $<$ span class="sc" $>\mathrm{d}<$ /span $>-$ Methionine as a Novel Oral Radiation Protector for Prevention of Mucositis. Clin Cancer Res 2008;14:2161-70.

37. Whitney J, Phillips L, Aslam R, et al. Guidelines for the treatment of pressure ulcers. Wound Repair Regen 2006;14:663-79.

38. Yasuda T, Chiba H, Satomi T, et al. Preventive effect of rebamipide gargle on chemoradiotherpy-induced oral mucositis in patients with oral cancer: a pilot study. J Oral Maxillofac Res 2012;2:e3.

39. Yokota T, Hamauchi S, Yoshida Y, et al. A phase II study of $\mathrm{HMB} / \mathrm{Arg} / \mathrm{Gln}$ against oral mucositis induced by chemoradiotherapy for patients with head and neck cancer. Support Care Cancer 2018;26:3241-8.

40. Yokota T, Ogawa T, Takahashi S, et al. Efficacy and safety of rebamipide liquid for chemoradiotherapyinduced oral mucositis in patients with head and neck cancer: a multicenter, randomized, double-blind, placebocontrolled, parallel-group phase II study. BMC Cancer 2017;17:314.

41. Yu HB, Kielczewska A, Rozek A, et al. Sequestosome-1/ p62 is the key intracellular target of innate defense regulator peptide. J Biol Chem 2009;284:36007-11.

42. Marín-Conde F, Castellanos-Cosano L, Pachón-Ibañez $\mathrm{J}$, et al. Photobiomodulation with low-level laser therapy reduces oral mucositis caused by head and neck radiochemotherapy: prospective randomized controlled trial. Int J Oral Maxillofac Surg 2019;48:917-23.

43. Zecha JA, Raber-Durlacher JE, Nair RG, et al. Low level laser therapy/photobiomodulation in the management of side effects of chemoradiation therapy in head and neck cancer: part 1: mechanisms of action, dosimetric, and safety considerations. Support Care Cancer 2016;24:2781-92.

44. Huang CJ, Huang MY, Fang PT, et al. Randomized double-blind, placebo-controlled trial evaluating oral glutamine on radiation-induced oral mucositis and dermatitis in head and neck cancer patients. Am J Clin Nutr 2019;109:606-14.

45. Chitapanarux I, Tungkasamit T, Petsuksiri J, et al. Randomized control trial of benzydamine $\mathrm{HCl}$ versus sodium bicarbonate for prophylaxis of concurrent chemoradiation-induced oral mucositis. Support Care Cancer 2018;26:879-86.

46. Rastogi M, Khurana R, Revannasiddaiah S, et al. Role of benzydamine hydrochloride in the prevention of oral mucositis in head and neck cancer patients treated with radiotherapy (>50 Gy) with or without chemotherapy. Support Care Cancer 2017;25:1439-43.

47. Wong KH, Kuciejewska A, Sharabiani MTA, et al. A randomised controlled trial of Caphosol mouthwash in management of radiation-induced mucositis in head and neck cancer. Radiother Oncol 2017;122:207-11.

48. Giralt J, Tao Y, Kortmann RD, et al. Randomized Phase 2 Trial of a Novel Clonidine Mucoadhesive Buccal Tablet for the Amelioration of Oral Mucositis in Patients Treated With Concomitant Chemoradiation Therapy for Head and Neck Cancer. Int J Radiat Oncol Biol Phys 2020;106:320-8.

49. Huang BS, Wu SC, Lin CY, et al. The effectiveness of a saline mouth rinse regimen and education programme on radiation-induced oral mucositis and quality of life in oral cavity cancer patients: A randomised controlled trial. Eur J Cancer Care (Engl) 2018;27:e12819.

50. Dong T, Reed A, Jones GC, et al. Retrospective Analysis 
of Prophylactic Gabapentin on Pain and Weight Loss in Patients Undergoing Radiation Therapy for Oropharyngeal Cancer. Int J Radiat Oncol Biol Phys 2016;94:893-4.

51. Kataoka T, Kiyota N, Shimada T, et al. Randomized trial of standard pain control with or without gabapentin for pain related to radiation-induced mucositis in head and neck cancer. Auris Nasus Larynx 2016;43:677-84.

52. Momo K, Nagaoka H, Kizawa Y, et al. Assessment of indomethacin oral spray for the treatment of oropharyngeal mucositis-induced pain during anticancer therapy. Support Care Cancer 2017;25:2997-3000.

53. DE Sanctis V, Belgioia L, Cante D, et al. Lactobacillus brevis CD2 for Prevention of Oral Mucositis in Patients With Head and Neck Tumors: A Multicentric Randomized Study. Anticancer Res 2019;39:1935-42.

54. Legouté F, Bensadoun RJ, Seegers V, et al. Low-level laser therapy in treatment of chemoradiotherapy-induced mucositis in head and neck cancer: results of a randomised, triple blind, multicentre phase III trial. Radiat Oncol 2019; 14:83.

55. Sio TT, Blanchard MJ, Novotny PJ, et al. N-Acetylcysteine Rinse for Thick Secretion and Mucositis of Head and Neck Chemoradiotherapy (Alliance MC13C2): A DoubleBlind Randomized Clinical Trial. Mayo Clin Proc 2019;94:1814-24.

56. Demir Doğan M, Can G, Meral R. Effectiveness of Black Mulberry Molasses in Prevention of RadiotherapyInduced Oral Mucositis: A Randomized Controlled Study in Head and Neck Cancer Patients. J Altern Complement Med 2017;23:971-9.

57. Ghalayani P, Emami H, Pakravan F, et al. Comparison of triamcinolone acetonide mucoadhesive film with licorice mucoadhesive film on radiotherapy-induced oral mucositis: A randomized double-blinded clinical trial. Asia Pac J Clin Oncol 2017;13:e48-e56.

58. Onseng K, Johns NP, Khuayjarernpanishk T, et al. Beneficial Effects of Adjuvant Melatonin in Minimizing Oral Mucositis Complications in Head and Neck Cancer Patients Receiving Concurrent Chemoradiation. J Altern Complement Med 2017;23:957-63.

59. Delavarian Z, Pakfetrat A, Ghazi A, et al. Oral administration of nanomicelle curcumin in the prevention of radiotherapy-induced mucositis in head and neck cancers. Spec Care Dentist 2019;39:166-72.

60. Marucci L, Farneti A, Di Ridolfi P, et al. Double-blind randomized phase III study comparing a mixture of natural agents versus placebo in the prevention of acute mucositis during chemoradiotherapy for head and neck cancer. Head Neck 2017;39:1761-9.

61. Jiang C, Wang H, Xia C, et al. A randomized, doubleblind, placebo-controlled trial of probiotics to reduce the severity of oral mucositis induced by chemoradiotherapy for patients with nasopharyngeal carcinoma. Cancer 2019;125:1081-90.

62. Elyasi S, Hosseini S, Niazi Moghadam MR, et al. Effect of Oral Silymarin Administration on Prevention of Radiotherapy Induced Mucositis: A Randomized, DoubleBlinded, Placebo-Controlled Clinical Trial. Phytother Res 2016;30:1879-85.

63. Charalambous M, Raftopoulos V, Paikousis L, et al. The effect of the use of thyme honey in minimizing radiation - induced oral mucositis in head and neck cancer patients: A randomized controlled trial. Eur J Oncol Nurs 2018;34:89-97.

64. Wang C, Wang P, Ouyang H, et al. Efficacy of Traditional Chinese Medicine in Treatment and Prophylaxis of Radiation-Induced Oral Mucositis in Patients Receiving Radiotherapy: A Randomized Controlled Trial. Integr Cancer Ther 2018;17:444-50.

65. Aghamohammadi A, Moslemi D, Akbari J, et al. The effectiveness of Zataria extract mouthwash for the management of radiation-induced oral mucositis in patients: a randomized placebo-controlled double-blind study. Clin Oral Investig 2018;22:2263-72.

66. Yokota T, Tachibana H, Konishi T, et al. Multicenter phase II study of an oral care program for patients with head and neck cancer receiving chemoradiotherapy. Support Care Cancer 2016;24:3029-36.

67. Kawashita Y, Koyama Y, Kurita H, et al. Effectiveness of a comprehensive oral management protocol for the prevention of severe oral mucositis in patients receiving radiotherapy with or without chemotherapy for oral cancer: a multicentre, phase II, randomized controlled trial. Int J Oral Maxillofac Surg 2019;48:857-64.

68. Bonfili P, Gravina GL, Marampon F, et al. Oral Platelet Gel Supernatant Plus Supportive Medical Treatment Versus Supportive Medical Treatment in the Management of Radiation-induced Oral Mucositis: A Matched Explorative Active Control Trial by Propensity Analysis. Am J Clin Oncol 2017;40:336-41.

69. Lee JE, Anderson CM, Perkhounkova Y, et al. Transcutaneous Electrical Nerve Stimulation Reduces Resting Pain in Head and Neck Cancer Patients: A Randomized and Placebo-Controlled Double-Blind Pilot Study. Cancer Nurs 2019;42:218-28. 
70. Iovoli AJ, Hermann GM, Ma SJ, et al. Non-steroidal antiinflammatory drug use is associated with improved survival in head and neck cancer. JAMA Open Network 2020.

[Epub ahead of print].

Cite this article as: Judge LF, Farrugia MK, Singh AK. Narrative review of the management of oral mucositis during chemoradiation for head and neck cancer. Ann Transl Med 2021;9(10):916. doi: 10.21037/atm-20-3931
71. Salvo N, Barnes E, van Draanen J, et al. Prophylaxis and management of acute radiation-induced skin reactions: a systematic review of the literature. Curr Oncol 2010;17:94-112. 


\section{Supplementary}

Start of treatment: (1) Rinses 20 times per day (2) Home Humdification

\begin{tabular}{|c|c|c|c|c|c|c|}
\hline \multicolumn{3}{|c|}{$\uparrow$ Gabapentin $\mathbf{3 0 0} \mathbf{~ m g}$ per day escalating } & \multicolumn{4}{|c|}{ Day 12 to end of treatment: $1200 \mathrm{mg}$ TID } \\
\hline & & & \multicolumn{4}{|c|}{ BMX or Doxepin per instructions } \\
\hline & & & \multicolumn{4}{|c|}{ Alternating Ibuprofen $400 \mathrm{mg}$ then Acetaminophen $1000 \mathrm{mg}$ as needed } \\
\hline & & & & & \multicolumn{2}{|c|}{ Methadone 2-5 mg TID if needed } \\
\hline Week 1 & Week 2 & Week 3 & Week 4 & Week 5 & Week 6 & Week 7 \\
\hline
\end{tabular}

1) Rinse/Gargle: Oral saline/bicarbonate rinses help with oral hygiene and the reduction of thick secretions. Begin using this 20 times per day and increase as your phlegm increases.

1 pint of room temperature water

1 tsp. salt

1 tsp. baking soda

**Keep rinse at different sinks around the house. Have a travel container to use for rinsing when away from home. Rinse, gargle, and spit. You would be better off making this by the gallon. There are 8 pints to a gallon, so you can multiply the recipe by eight.

2) Gabapentin (Neurontin): Gabapentin is frequently prescribed to reduce neuropathic pain in a variety of settings. This medication is intended to prevent and control pain from your treatment. You should take $300 \mathrm{mg}$ to start. However, take this dose once on the first day, twice on the second day. Begin taking three $300 \mathrm{mg}$ doses on the third day. If well tolerated, you should continue to escalate the dosage as below: ${ }^{* *}$ Once you reach $1200 \mathrm{mg} 3 \mathrm{x}$ a day, continue this dose throughout the rest of treatment. Liquid formulations are available if needed.

\begin{tabular}{|l|c|c|c|c|c|c|c|c|c|c|c|c|}
\hline & Day 1 & Day 2 & Day 3 & $\begin{array}{c}\text { 1st } \\
\text { escaltion } \\
\text { Day 4) }\end{array}$ & $\begin{array}{c}\text { 2nd } \\
\text { escaltion } \\
\text { (Day 5) }\end{array}$ & $\begin{array}{c}\text { 3rd } \\
\text { escalation } \\
\text { (Day 6) }\end{array}$ & $\begin{array}{c}4 \text { th } \\
\text { escalation } \\
\text { (Day 7) }\end{array}$ & $\begin{array}{c}\text { 5th } \\
\text { escalation } \\
\text { (Day 8) }\end{array}$ & $\begin{array}{c}\text { 7th } \\
\text { escalation } \\
\text { (Day 9) }\end{array}$ & $\begin{array}{c}\text { 8th } \\
\text { escalation } \\
\text { (Day 10) }\end{array}$ & $\begin{array}{c}9^{\text {th }} \text { escalation } \\
\text { (Day 11) }\end{array}$ & $\begin{array}{c}\text { FINAL } \\
\text { (Day 12-end of } \\
\text { treatment }\end{array}$ \\
\hline Breakfast & $\times$ & $300 \mathrm{mg}$ & $300 \mathrm{mg}$ & $300 \mathrm{mg}$ & $300 \mathrm{mg}$ & $600 \mathrm{mg}$ & $600 \mathrm{mg}$ & $600 \mathrm{mg}$ & $900 \mathrm{mg}$ & $900 \mathrm{mg}$ & $900 \mathrm{mg}$ & $1200 \mathrm{mg}$ \\
\hline Lunch & $\times$ & $\times$ & $300 \mathrm{mg}$ & $300 \mathrm{mg}$ & $600 \mathrm{mg}$ & $600 \mathrm{mg}$ & $600 \mathrm{mg}$ & $900 \mathrm{mg}$ & $900 \mathrm{mg}$ & $900 \mathrm{mg}$ & $1200 \mathrm{mg}$ & $1200 \mathrm{mg}$ \\
\hline Dinner & $300 \mathrm{mg}$ & $300 \mathrm{mg}$ & $300 \mathrm{mg}$ & $600 \mathrm{mg}$ & $600 \mathrm{mg}$ & $600 \mathrm{mg}$ & $900 \mathrm{mg}$ & $900 \mathrm{mg}$ & $900 \mathrm{mg}$ & $1200 \mathrm{mg}$ & $1200 \mathrm{mg}$ & $1200 \mathrm{mg}$ \\
\hline
\end{tabular}

3) BMX: This liquid medication (Benadryl, Maalox, and Xylocaine) is used to relieve pain in the mouth and throat for a short period of time (15 minutes). We recommend patients use this when they have mouth and throat pain associated with radiation treatments. We recommend taking this medication 3 minutes before meals (to help them swallow) and at bedtime.

- Swish and swallow- You can swallow this medication up to $4 x$ per day

- Swish and spit-You can do this between 8-12x per day

- Topical application onto sore areas in the mouth- You can apply BMX onto sponge sticks (provided) and then onto the sore areas in the mouth throughout the day as needed for pain. This gives you pain relief without making your whole mouth numb.

4) Ibuprofen / Acetaminophen: If patients are having pain not controlled with the above regimen, we recommend starting alternating Ibuprofen $400 \mathrm{mg}$ and Tylenol $1000 \mathrm{mg}$ (IE Ibuprofen $400 \mathrm{mg}$ and 4 hours later, take Tylenol $1000 \mathrm{mg}$ ). This can be repeated every 6-8 hours however maximum recommended daily dose of Acetaminophen is $3000 \mathrm{mg}$. Formulations are available in liquid if needed

5) Methadone: Pain control can be difficult towards the end of treatment. For those whose pain is not adequately controlled non-opiate pharmaceuticals, we recommend starting Methadone $2 \mathrm{mg}$ TID and increasing if needed to $5 \mathrm{mg}$ TID. This should be available in liquid formulation if needed ( $1 \mathrm{mg} / \mathrm{mL}$ ).

*** When weaning pain medications, we recommend starting with the reverse of the order added. For example, as Methadone is the last medication added, weaning should begin with Methadone. Gabapentin weaning should be done in the reverse order of escalation as per the table above. 